\title{
Decreased Lysosomal Dipeptidyl Aminopeptidase I Activity in Cultured Human Skin
}

\section{Fibroblasts in Duchenne's Muscular Dystrophy}

\author{
Benjamin B. Gelman, Linda Papa, Michael H. Davis, and Eric Gruenstein, \\ Department of Biological Chemistry, University of Cincinnati College of \\ Medicine, Cincinnati, Ohio 45267
}

\begin{abstract}
A B S T RACT Several lysosomal enzymes were assayed in cultured human skin fibroblasts from patients with Duchenne's muscular dystrophy (DMD) and age- and sex-matched control patients $(\mathrm{N})$. The activity of four glycosidases, cathepsin $B_{1}$, and total autoproteolysis at $\mathrm{pH} 4.0$ were unchanged between the groups, but dipeptidyl aminopeptidase I (DAP-I, or cathepsin C) in the DMD cells was found to be only $30 \%$ as active as in the control cells $(P<0.003)$. This difference is not the result of a redistribution or loss of enzyme during homogenization because the difference occurs in all homogenate fractions. DAP-I activity existing in $\mathrm{N}$ and DMD fibroblasts behaves identically with respect to activation by chloride ion, activation by the sulfhydryl reducing agent dithiothreitol, changes in hydrogen ion concentration $(\mathrm{pH})$, changes in substrate concentration (i.e., apparent $K_{\mathrm{m}}$ values), and changes in temperature (i.e., apparent activation energies). Mixtures of $\mathrm{N}$ and DMD cell sonicates display an additivity in DAP-I activity. These results support the conclusion that the catalytic function of the DAP-I molecule is equivalent between $\mathrm{N}$ and DMD fibroblasts, and that the decrease in tissuespecific DAP-I activity probably results from the fact that fewer enzyme molecules are present in the DMD cells. These results are also an indication that these nonmuscle cells are expressing some of the phenotypic aspects of the genetic defect in DMD. Cultured human skin fibroblasts may therefore be a useful cellular model in DMD research.
\end{abstract}

\section{INTRODUCTION}

Duchenne's muscular dystrophy (DMD) ${ }^{1}$ is the most prevalent form of the inherited muscular dystrophies

Address reprint requests to Dr. Gruenstein.

Received for publication 15 October 1979 and in revised form 28 January 1980.

${ }^{1}$ Abbreviations used in this paper: DAP-I, dipeptidyl aminopeptidase I; DMD, Duchenne's muscular dystrophy; DTT, dithiothreitol; $V_{\max }$, maximum velocity. and is transmitted as an X-linked recessive gene (1). The precise metabolic defect underlying the disease process is not yet known. A major obstacle in biochemical studies of dystrophic muscle has been the extensive secondary changes that occur in the degenerating skeletal muscle which serve to obscure the primary error of metabolism. Thus, there are reports of alterations in the levels of DMD skeletal muscle lipids $(2,3)$, adenylate cyclase activity (4-6), activity of the sarcotubular system (7), protein synthesis (8), plasma membrane structure $(9,10)$ and the activity of several lysosomal proteases (11-17). The fact that nonmuscle tissues are also affected clinically, although less critically, has suggested that the primary error might also be expressed in other organ systems (1). For example, circulating erythrocytes from DMD patients have recently been studied to test the hypothesis that the primary lesion in DMD involves a generalized defect in the structure and function of the plasma membrane (1). The use of erythrocytes as model cells in plasma membrane research is firmly established, but the relative lack of metabolic and substructural complexity of these cells may limit their application to studies of subcellular structures, their membranes, and their related physiological functions.

Cultured fibroblasts obtained from explants of human skin biopsies have proved to be a very useful cell model for investigating a variety of inborn errors of metabolism. These cells possess highly complex structural and functional characteristics that make them suitable for the study of many aspects of cellular metabolism. Studies of cultured fibroblasts from DMD patients have been initiated only very recently, however, and the results reported thus far indicate that the growth characteristics and longevity in culture of these cells is normal (18), suggesting that study of these cells is not subject to the secondary changes imposed by progressive degeneration. There are also reports of altered collagen metabolism and of altered ultrastructural morphology $(19,20)$ in DMD fibroblasts, but these 
results were not confirmed in other laboratories $(21$, 22). A preliminary report of decreased in vitro protein synthesis with isolated polysomes from DMD fibroblasts also appeared recently (23). A further indication that the DMD gene is phenotypically expressed in nonmuscle cells comes from the recent finding that lymphocyte capping is defective in DMD patients, DMD carriers, and in certain other primary myopathies (24).

Our approach to the study of DMD fibroblasts has been to examine the lysosomal characteristics of these cells. During the course of these studies, it was observed that the lysosomal enzyme dipeptidyl aminopeptidase I (DAP-I) (EC 3.4.14.1), also known as "cathepsin C," was on the average only $30 \%$ as active in the DMD cells compared with age- and sex-matched control cells. The purpose of this report, therefore, is to fully describe this difference and to present the results of experiments designed to determine whether this effect represents a change in the enzyme resulting in decreased catalytic efficiency of the protein molecule, or whether it represents a secondary change wherein fewer enzyme molecules are present in the DMD cells.

\section{METHODS}

Cells. For this study eight lines of fibroblasts from DMD patients and six age- and sex-matched normal controls were used. The sources of the various cell lines and the age and sex of the donors is given in Table I. Six of the DMD lines and four of the control lines were obtained from the Repository for Mutant Human Cell Strains, Montreal, Canada. Two of the control lines were obtained from the Institute for Medical Research, Camden, N. J., and two of the DMD lines were developed in our laboratory from skin biopsies obtained from patients at the Neurology Clinic of the University of Cincinnati Medical Center. Cells were cultured in $100 \times 20 \mathrm{~mm}$ Falcon plastic culture dishes (Falcon Labware, Div. Becton, Dickinson \& Co., Oxnard, Calif.) in a humidity controlled incubator (Forma Scientific, Div. Mallinckrodt, Inc., Marietta, Ohio) at $37^{\circ} \mathrm{C}$ and $5 \% \mathrm{CO}_{2}$. The growth medium ( $\left.10 \mathrm{ml} / \mathrm{plate}\right)$ consisted of Earle's minimum essential medium (Gibco Laboratories, Grand Island Biological Co., Grand Island, N. Y.) plus $100 \mathrm{U} / \mathrm{ml}$ penicillin, $0.1 \mu \mathrm{g} / \mathrm{ml}$ streptomycin, $1 \%$ (vol/vol) nonessential amino acids (Gibco Laboratories) $10 \%$ (vol/vol) fetal calf serum (Gibco Laboratories), 20 $\mathrm{mM}$ Tricine, and $24 \mathrm{mM} \mathrm{NaHCO}$ (Sigma Chemical Co., St. Louis, Mo.). Cells were passaged using $0.04 \%$ trypsin solution and received fresh medium every $2 \mathrm{~d}$. All cell lines were between passage 10 and 35 during the course of these experiments. The decrease in DMD DAP-I activity was present in the early passage cells and persisted throughout the course of the experiments. For any given experiment, all cell lines were at the same passage number \pm 2 . All experiments were done on confluent cells because DAP-I specific activity is lower in log phase cells and increases to a plateau as cells become confluent (data not shown). Special care was taken to handle each cell line separately to avoid crosscontamination of the cultures. All cell lines were tested for mycoplasma and found to be mycoplasma-free at the beginning and end of this study.

Cell disruption. Cells were prepared for enzyme analysis by homogenization, sonication, or freeze-thaw procedure, depending on the particular experiment. (a) For experiments with intact lysosomes, cells were homogenized in a PotterElvehjem homogenizer as follows. Cells were rinsed twice with ice-cold $0.25 \mathrm{M}$ sucrose and scraped off the culture dish with a rubber policeman into $3.0 \mathrm{ml}$ of ice-cold $0.25 \mathrm{M}$ sucrose. The cells were then passed 20 times through a Kontes 23 Teflon-glass tissue grinder (Kontes Co., Vineland, N. J.) with the pestle rotating at $200 \mathrm{rpm}$. The homogenate was centrifuged at $750 \mathrm{~g}$ for $10 \mathrm{~min}\left(4^{\circ} \mathrm{C}\right)$, and a crude lysosomal pellet was prepared by centrifuging the postnuclear supernate at $30,000 \mathrm{~g}$ for $20 \mathrm{~min}$ at $4^{\circ} \mathrm{C}$. The pellet was suspended in ice-cold $0.25 \mathrm{M}$ sucrose for assay of DAP-I activity. (b) For studies of the kinetic characteristics of DAP-I activity, sonication was used to simultaneously disrupt both cells and lysosomes. Cells were rinsed twice with $0.25 \mathrm{M}$ sucrose at $4^{\circ} \mathrm{C}$, scraped into $3.0 \mathrm{ml}$ of ice-cold distilled deionized water, and sonicated for $60 \mathrm{~s}$ with a Kontes micro-ultrasonic cell disrupter at maximum power. $(c)$ For studies on autoproteolysis, a freeze-thaw procedure was used because preliminary studies showed that this method preserved maximal proteolytic activity (data not shown). Cells were rinsed with ice-cold phosphate-buffered saline, $\mathrm{pH}=7.4$ and then

TABLE I

Source of Cultured Human Skin Fibroblasts

\begin{tabular}{|c|c|c|c|c|c|c|c|}
\hline \multicolumn{4}{|c|}{ Normal } & \multicolumn{4}{|c|}{ Dystrophic } \\
\hline Cell line & Donor age & Sex & Source & Cell line & Donor age & Sex & Source \\
\hline & $y r$ & & & & $y r$ & & \\
\hline MC 35 & 3 & $\mathbf{M}$ & Montreal* & MG 348 & 4.5 & $\mathbf{M}$ & Montreal* \\
\hline MC 20 & 4 & $\mathbf{M}$ & Montreal* & $\mathrm{AB} 001$ & 5 & $\mathbf{M}$ & Cincinnati \\
\hline GM 497 & 4 & M & Camden§ & WG 502 & 5.5 & M & Montreal* \\
\hline MC 40 & 6 & $\mathbf{M}$ & Montreal* & TG 002 & 5.5 & $\mathbf{M}$ & Cincinnatił \\
\hline MC 31 & 8 & $\mathbf{M}$ & Montreal* & WG 466 & 6 & $\mathbf{M}$ & Montreal* \\
\hline \multirow[t]{3}{*}{ GM 2,987 } & 19 & $\mathbf{M}$ & Camden§ & WG 448 & 6 & M & Montreal* \\
\hline & & & & WG 280 & 7 & $\mathbf{M}$ & Montreal* \\
\hline & & & & WG 433 & 18 & 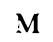 & Montreal* \\
\hline
\end{tabular}

* Repository for Mutant Human Cell Strains, Montreal, Canada.

\$ Neurology Clinic, University of Cincinnati Medical Center, Cincinnati, Ohio.

$\S$ Institute for Medical Research, Camden, N. J. 
treated with $0.2 \%$ trypsin solution to remove them from the culture dish. The cells were harvested in culture medium containing $10 \%$ fetal calf serum to inhibit trypsin activity, pelleted at $750 \mathrm{~g}$ for $10 \mathrm{~min}$ at $4^{\circ} \mathrm{C}$, washed twice with ice-cold phosphate-buffered saline by successive centrifugation and resuspension to remove trypsin, and then suspended in icecold $0.1 \mathrm{M}$ acetate-borate-cacodylate $(0.033 \mathrm{M}$ of each) buffer adjusted to varying $\mathrm{pH}$ values as indicated in the figure legends $(6 \mathrm{ml} /$ plate). The suspensions were then frozen and thawed six times in a dry ice-ethanol bath to rupture both cellular and lysosomal membranes.

Assays. DAP-I was assayed fluorometrically using glycyl-Lphenylalanine- $\beta$-naphthylamide as substrate (Vega-Fox Biochemicals, Div. Newberg Energy Corp., Tucson, Ariz.) (25). Except where otherwise specified in the figures, the reaction contained $0.1 \mathrm{mM}$ substrate, $1.0 \mathrm{mM}$ dithiothreitol, $30 \mathrm{mM}$ $\mathrm{NaCl}, 1.0 \mathrm{mM}$ disodium EDTA, and $0.05 \mathrm{M}$ sodium acetate buffer, pH 5.0, in a final volume of $0.2 \mathrm{ml}$. The reaction was stopped after $15-60 \mathrm{~min}$ of incubation at $37^{\circ} \mathrm{C}$ by adding $2.0 \mathrm{ml}$ of $50 \mathrm{mM}$ glycine- $\mathrm{NaOH}$ buffer, $\mathrm{pH} 10.4$, containing $5 \mathrm{mM}$ disodium EDTA. The liberated $\beta$-naphthylamine was measured on an Aminco-Bowman (American Instrument Co., Travenol Laboratories, Silver Spring, Md.) spectrophotofluorometer at $335 \mathrm{~nm}$ (excitation) and $405 \mathrm{~nm}$ (emission). Standards were prepared from commercially obtained $\beta$-naphthylamine (Sigma Chemical Co.) and the results are expressed as nanomoles liberated per milligram cell protein per hour.

Cathepsin $\mathrm{B}_{1}$ (EC 3.4.22.1) was assayed fluorometrically using $N$ - $\alpha$-benzoyl-DL-arginine- $\beta$-naphthylamide (Vega-Fox Biochemicals) as substrate (25). The reaction contained 0.1 $\mathrm{mM}$ substrate, $0.5 \mathrm{mM}$ dithiothreitol, $1.0 \mathrm{mM}$ disodium EDTA, $0.05 \%$ Triton X-100 (vol/vol), and $0.05 \mathrm{mM}$ sodium acetate buffer, $\mathrm{pH} 5.0$, in a final volume of $0.2 \mathrm{ml}$. After incubation for $15-60 \mathrm{~min}$ at $37^{\circ} \mathrm{C}$ the reaction was stopped and the fluorescence was measured as described above for the DAP-I assay. Activity is expressed as nanomoles $\beta$ naphthylamine liberated per milligram cell protein per hour.

$\beta$-glucuronidase (EC 3.2.1.31), $\beta$-glucosidase (EC 3.2.1.21), $\beta$-galactosidase (EC 3.2.1.23), and $\alpha$ - $N$-acetylgalactosaminidase (EC 3.2.1.49) were assayed using 4-methylumbelliferyl substrates (Sigma Chemical Co.) (26). The reaction mixtures contained $0.05 \mathrm{M}$ sodium acetate buffer at $\mathrm{pH}$ values of $4.3,5.3,4.1$, and 5.3 , respectively. Also included in the assays were $0.1 \mathrm{mM}$ of 4-methylumbelliferyl substrates and $0.05 \%$ Triton X-100 (vol/vol), except for $\beta$-glucosidase, which contained $0.01 \%$ Triton $X-100$. Assays were incubated for $15-60 \mathrm{~min}$ at $37^{\circ} \mathrm{C}$ in a final volume of $0.2 \mathrm{ml}$, and were stopped as described above for the DAP-I assay. The liberated 4-methylumbelliferone was measured fluorometrically at 365 $\mathrm{nm}$ (excitation) and $460 \mathrm{~nm}$ (emission) using commercially obtained 4-methylumbelliferone as standard. The results are expressed as nanomoles 4-methylumbelliferone liberated per milligram cell protein per hour.

Total acid autoproteolysis was assayed on cells that had been incubated for $12 \mathrm{~h}$ in growth medium supplemented with $25 \mu \mathrm{Ci}$ each of $\left[{ }^{3} \mathrm{H}\right]$ lysine and $\left[{ }^{3} \mathrm{H}\right]$ arginine to label cellular proteins. Cells were harvested, disrupted, and suspended according to the freeze-thaw procedure as described above. The buffered ( $\mathrm{pH} 4.0$ ) suspensions were incubated aerobically at $37^{\circ} \mathrm{C}$, and aliquots were removed periodically for analysis of TCA-soluble radioactivity. The aliquots were precipitated in a final TCA concentration (wt/vol) of $10 \%$ along with $3 \mathrm{mg} / \mathrm{ml}$ of bovine serum albumin added as a carrier protein. The TCAprecipitable and TCA-soluble fractions were separated by centrifugation at $750 \mathrm{~g}$ for $10 \mathrm{~min}$ at $23^{\circ} \mathrm{C}$, aliquots of the supernate were solubilized with NCS (Amersham Corp., Arlington Heights, Ill.), and the radioactivity was counted in a PPOtoluene-POPOP scintillation cocktail using a Beckman LS-335 liquid scintillation counter (Beckman Instruments, Fullerton, Calif.). Autoproteolysis was expressed as the percentage of the total counts that were TCA-soluble after $3.5 \mathrm{~h}$ of incubation at pH 4.0 minus the TCA-soluble activity at the start of the incubation. Under these conditions, autoproteolysis was linear over the first $4 \mathrm{~h}$ of incubation and was linear with respect to cell protein concentration (data not shown).

Protein concentration was assayed using the procedure of Lowry et al. (27) with bovine serum albumin serving as standards. The statistical comparisons were based on the twotailed $t$ test (28). The level of significance chosen was $P<0.05$.

\section{RESULTS}

The results of various lysosomal assays on normal and DMD fibroblasts are shown in Table II. The activity of four glycosidases and cathepsin $B_{1}$ were unchanged between the groups. However, DAP-I activity was significantly lower in the DMD population. To test the possibility that this apparent difference might be caused by a redistribution of the enzyme during homogenization, DAP-I activity was assayed in each of the different homogenate fractions (Table III) and was found to be lower in the DMD cells in all cases. The possibility that the lower DAP-I activity observed in the DMD cells might result from increased loss of the enzyme through the plasma membrane and into the surrounding culture medium was also considered. This possibility is unlikely because it was found that DAP-I activity was undetectable in samples of 48-h culture medium from both normal and DMD cells despite use of a highly sensitive fluorometric assay (see Methods).

TABLE II

Lysosomal Characteristics of Normal and Duchenne Dystrophic Cultured Human Skin Fibroblasts

\begin{tabular}{lll}
\hline \multicolumn{1}{c}{ Parameter* } & \multicolumn{1}{c}{ Normal } & DMD \\
\hline$\beta$-glucuronidase activity & $22.1 \pm 2.8$ & $24.8 \pm 2.8$ \\
$\beta$-glucosidase activity & $22.3 \pm 2.0$ & $24.6 \pm 2.2$ \\
$\beta$-galactosidase activity & $97.7 \pm 11.4$ & $75.2 \pm 3.8$ \\
$N$-acetylgalactosaminidase & & \\
$\quad$ activity & $84.5 \pm 4.6$ & $79.7 \pm 2.5$ \\
Cathepsin B B $_{1}$ activity & $68.6 \pm 16.9$ & $60.3 \pm 12.2$ \\
Total acid autoproteolysis & $45.1 \pm 4.6$ & $37.9 \pm 5.3$ \\
DAP-I activity (Cathepsin C) & $773 \pm 223$ & $249 \pm 74 \ddagger$ \\
\hline
\end{tabular}

* Enzyme assays were performed on $30,000 \mathrm{~g}$ pellets from postnuclear supernates and the assay tubes contained, in addition to the components described in Methods, $0.02 \%$ ( $\mathrm{vol} / \mathrm{vol}$ ) Triton X-100. Activity is expressed as nanomoles of product formed per milligram cell protein per hour (mean $\pm S E M$ ). Total autoproteolysis was performed on cells disrupted by the freeze-thaw procedure as described in the Methods section and the results are expressed as the percentage of the total cell protein soluble in TCA after $3.5 \mathrm{~h}$ of aerobic incubation at $37^{\circ} \mathrm{C}($ mean $\pm \mathrm{SEM})$.

† Statistically significant difference from normal, $P<0.04$, two-tailed $t$ test. 
TABLE III

Lysosomal Enzyme Activities of Various Cell Fractions of Normal and Dystrophic Cultured Human Skin Fibroblasts

\begin{tabular}{lccc}
\hline \multicolumn{1}{c}{ Enzyme* } & $\begin{array}{c}\text { Postnuclear } \\
\text { supernate }\end{array}$ & $\begin{array}{c}30,000 \mathrm{~g} \\
\text { pellet }\end{array}$ & $\begin{array}{c}30,000 \mathrm{~g} \\
\text { supernate }\end{array}$ \\
\hline $\begin{array}{l}\beta \text {-D-glucosidase } \\
\text { Normal }\end{array}$ & $7.98 \pm 0.55$ & $22.3 \pm 2.0$ & $2.48 \pm 0.16$ \\
DMD & $8.76 \pm 0.66$ & $24.6 \pm 2.2$ & $2.21 \pm 0.11$ \\
$\beta$-D-glucuronidase & & & \\
$\quad$ Normal & $9.58 \pm 0.99$ & $22.1 \pm 2.8$ & $4.98 \pm 0.31$ \\
DMD & $10.82 \pm 1.12$ & $24.8 \pm 2.8$ & $5.32 \pm 0.45$ \\
$\beta$-D-galactosidase & & & \\
Normal & $87.7 \pm 1.6$ & $97.7 \pm 11.4$ & $39.0 \pm 5.5$ \\
DMD & $75.0 \pm 2.6$ & $75.2 \pm 3.8$ & $34.4 \pm 2.2$ \\
DAP-I & & & \\
Normal & $279 \pm 65$ & $773 \pm 223$ & $146 \pm 30$ \\
DMD & $95 \pm 23 \S$ & $249 \pm 74$ & $41 \pm 8 \pi$ \\
\hline
\end{tabular}

* Activity expressed as nanomoles product formed per milligram protein per hour and given as the mean $\pm \operatorname{SEM}, n$ $=6$ (normal) or 8 (dystrophic).

$\ddagger$ Assay contained $0.02 \%$ Triton X-100 in addition to the conditions described in Methods.

$\S$ Statistically, significant difference from normal, $P<0.01$, two-tailed $t$ test.

" $P<0.04$.

I $P<0.005$.

To verify the lysosomal nature of the DAP-I activity, postnuclear supernates were separated on continuous sucrose density equilibrium gradients and the gradient fractions were assayed for DAP-I activity. The sedimentation pattern of DAP-I activity is shown in Fig. 1 as activity per milliliter of aliquot (top panel) and as the percentage of the total enzyme activity in the gradient per aliquot (bottom panel). The data show that although there was less total DAP-I activity in the DMD gradients, the sedimentation pattern was the same between the DMD and normal groups. This sedimentation pattern was identical to that of other characteristic lysosomal enzymes (data not shown), confirming the lysosomal localization of this enzyme.

Individual values for tissue-specific DAP-I activity seen in the left panel of Fig. 2 show that despite the magnitude and the statistical significance of the difference between group means, the range of values is very broad, particularly in the normal population. The scattergrams in the three right panels depict DAP-I activity normalized to three other lysosomal enzymes. The rationale for expressing enzyme activity in this way is that the activity of these other lysosomal enzymes may be a more accurate estimate of the amount of lysosomal protein than the direct measurement of total protein concentration in the crude $30,000 \mathrm{~g}$ pellet which contains many other organelles. When DAP-I activity was expressed in this way, the variability was moderately decreased, thereby increasing the statistical significance of the differences in the means of the groups (the $P$ values decreased). The ranges of the two population samples are still seen to overlap in each case, but it should be noted that the overlap is limited to a single point when DAP-I activity is normalized to $\beta$-glucosidase units.

Studies of DAP-I activity purified from other tissues and species (29) have shown it to be a sulfhydryl
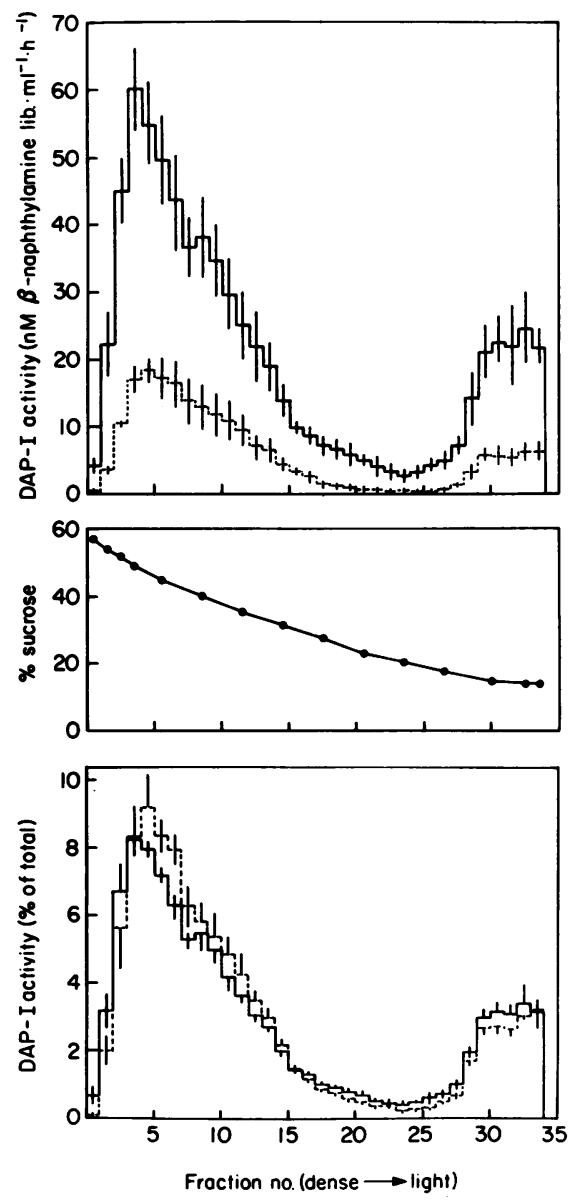

FIGURE 1 Distribution of DAP-I activity of normal (-) and DMD ( - - - ) cultured human skin fibroblasts separated on continuous sucrose equilibrium density gradients. Each gradient consisted of 4-ml cushion of saturated sucrose overlayed with $26 \mathrm{ml}$ of a $20-55 \%$ (wt/vol) linear sucrose gradient, and a final 4-ml overlay of postnuclear supernate prepared from a mixture of two different cell lines homogenized separately in ice-cold $0.25 \mathrm{M}$ sucrose containing $1 \mathrm{mM}$ disodium EDTA. Gradients were centrifuged for $90 \mathrm{~min}$ at $4^{\circ} \mathrm{C}$ using a Beckman VTI-50 vertical tube rotor in a Beckman L5-50 ultracentrifuge at $18,000 \mathrm{rpm}(27,500 \mathrm{~g})$ (Beckman Instruments), and $1.0-\mathrm{ml}$ fractions were collected using a Gilson Medical Electronics, Inc., Middleton, Wisc., FC-220K fraction collector. Data are given as the mean $\pm S E M$ for three gradients, each containing a mixture of two different cell lines. Lib, liberated. 


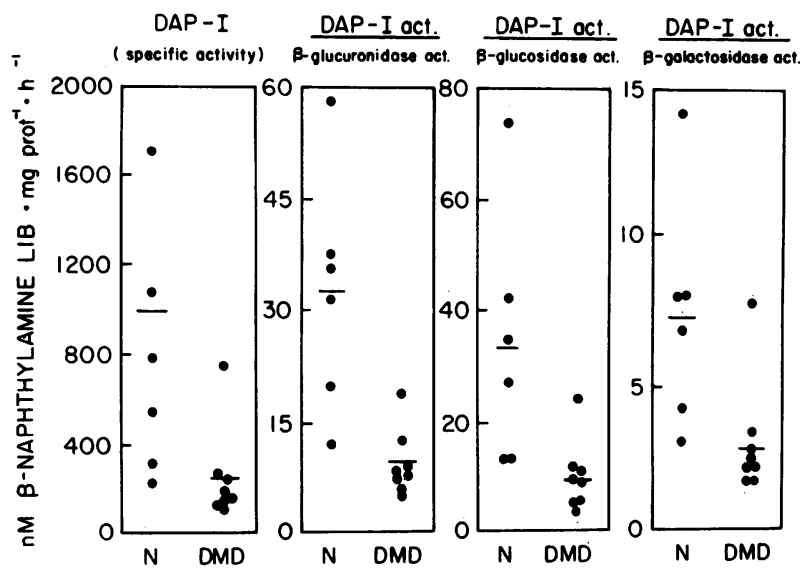

FIGURE 2 Scattergram of DAP-I activity in $30,000 \mathrm{~g}$ pellets from postnuclear supernates of normal (N) and DMD cultured human skin fibroblasts. The data are expressed as specific activity per milligram of protein and also as units of DAP-I activity normalized to the activity of three other lysosomal enzymes. From left to right, the difference between the means of normal and DMD cells was significant at $P$ values equal to $0.02,0.003,0.04$ and 0.02 , respectively, as determined by the two-tailed $t$ test.

enzyme with a requirement for halide ion that is virtually absolute. The activation of fibroblast DAP-I activity by chloride ion and by the sulfhydryl reducing agent dithiothreitol (DTT) in normal and DMD cells is shown in Figs. 3 and 4, respectively. The difference in DAP-I activity between the groups was still apparent after maximal activation by these two cofac-

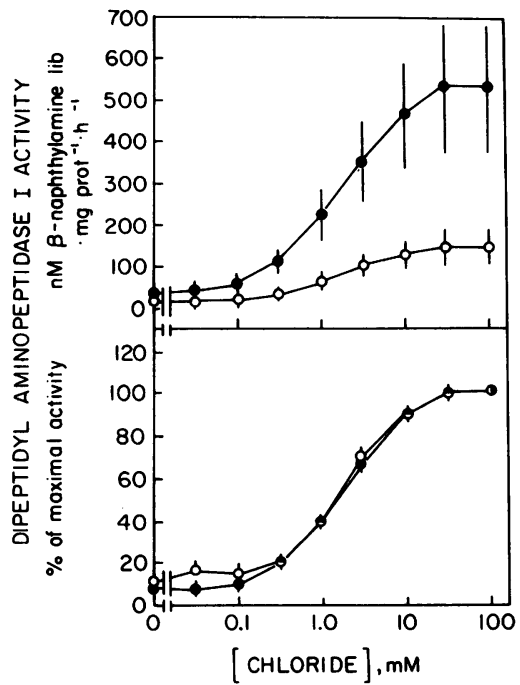

FIGURE 3 DAP-I activity in normal (- - -) and DMD $(-\mathrm{O}-)$ cultured human skin fibroblast sonicates assayed with the final $\mathrm{NaCl}$ concentrations shown on the abscissa. The data are depicted as the specific activity (upper) and as the percentage of activity at the maximal chloride concentration (lower). The data are given as the mean $\pm \mathrm{SEM}, n=6$ (normal) or 8 (dystrophic). Prot, protein. tors (upper panels). However, the dose-response curves for the two populations of cells are identical when expressed as the percentage of maximal activation (bottom panels), indicating that there is no difference in the chloride or DTT sensitivity of the DAPI molecules between DMD and normal cells.

The $\mathrm{pH}$ dependence of the enzyme was also observed to be identical between the two groups over a range of acid $\mathrm{pH}$ values (Fig. 5). The activity at neutral $\mathrm{pH}$ values for DAP-I is not reported here because it is known that DAP-I also catalyzes a "transferase" reaction at neutral and basic $\mathrm{pH}(29,30)$. This reaction is qualitatively different from the hydrolytic reaction at acid $\mathrm{pH}$, involving the formation of dipeptide polymers of varying complexity. This unusual ability of the enzyme to catalyze a different reaction at neutral $\mathrm{pH}$ is a potential source of interference in the accuracy of measurement DAP-I hydrolysis and is therefore the subject of a separate investigation in this laboratory.

The kinetic properties of DAP-I with the fluorogenic substrate glycyl-L-phenylalanine- $\beta$-naphthylamide is shown graphically on double-reciprocal plots (Fig. 6) and as numerical values for maximum velocity $\left(V_{\max }\right)$, and apparent $K_{\mathrm{m}}$ of the individual cell lines (Table IV).

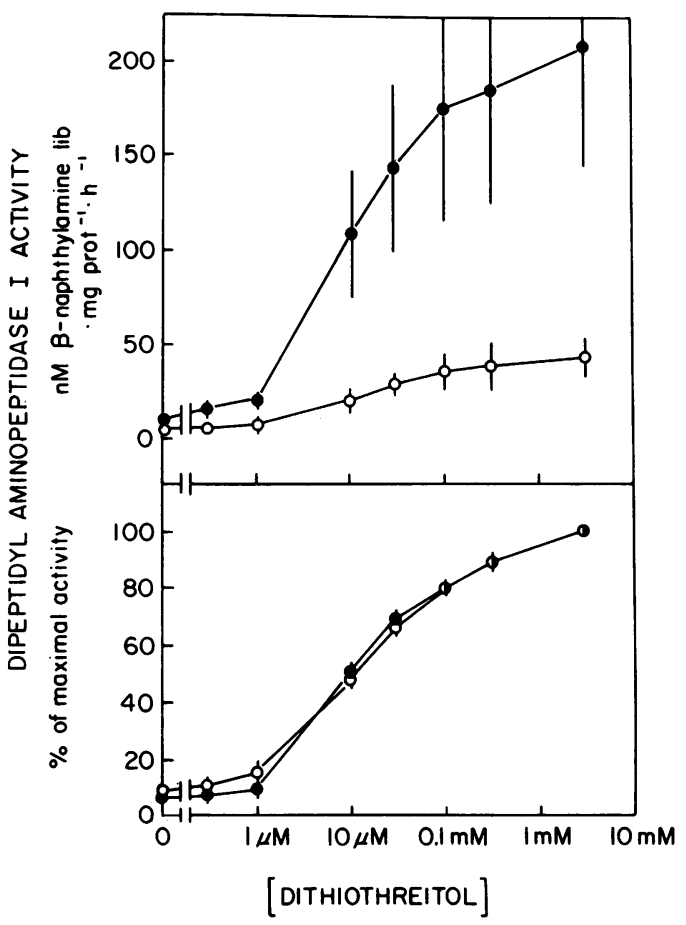

FIGURE 4 DAP-I activity in normal (- - ) and DMD $(-\mathrm{O}-)$ cultured human skin fibroblast sonicates assayed with the final DTT concentrations shown on the abscissa. Samples were preincubated with DTT at $37^{\circ} \mathrm{C}$ for $30 \mathrm{~min}$ before the addition of the substrate. The data are depicted as the specific activity (upper) and as the percentage of activity at the maximal DTT concentration (lower). The data are given as the mean $\pm \mathrm{SEM}, n=6$ (normal) or 8 (dystrophic). 


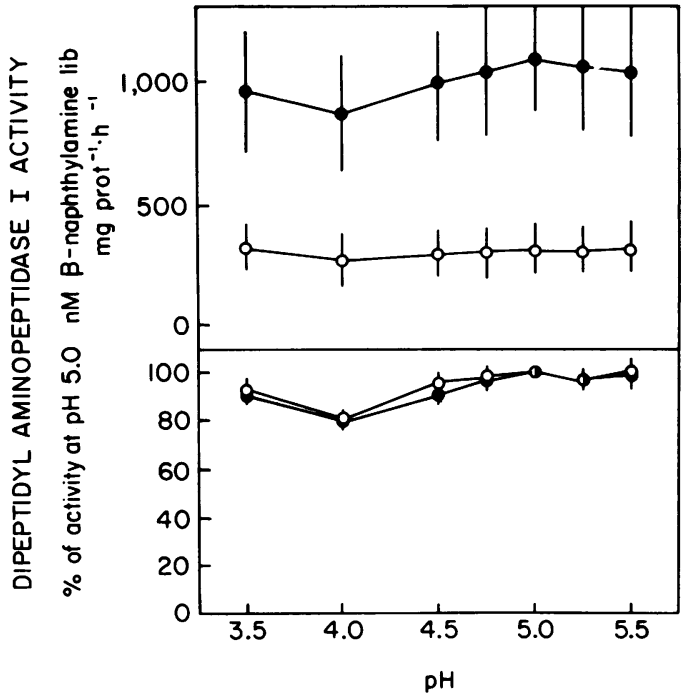

FIGURE 5 DAP-I activity in normal (- - ) and DMD $(-\mathrm{O}-)$ cultured human skin fibroblast sonicates assayed at the $\mathrm{pH}$ values shown on the abscissa. The data are depicted as the specific activity (upper) and as the percentage of the activity when $\mathrm{pH}=5.0$ (lower). The data are given as the mean $\pm \operatorname{SEM}, n=6$ (normal) or 8 (dystrophic).

The data show that $V_{\max }$ and the slope of the Lineweaver-Burk plots are different whereas the apparent $K_{\mathrm{m}}$ values are not significantly different between the groups. It should be noted that the considerable variability expressed as error bars in Fig. 6 is due to

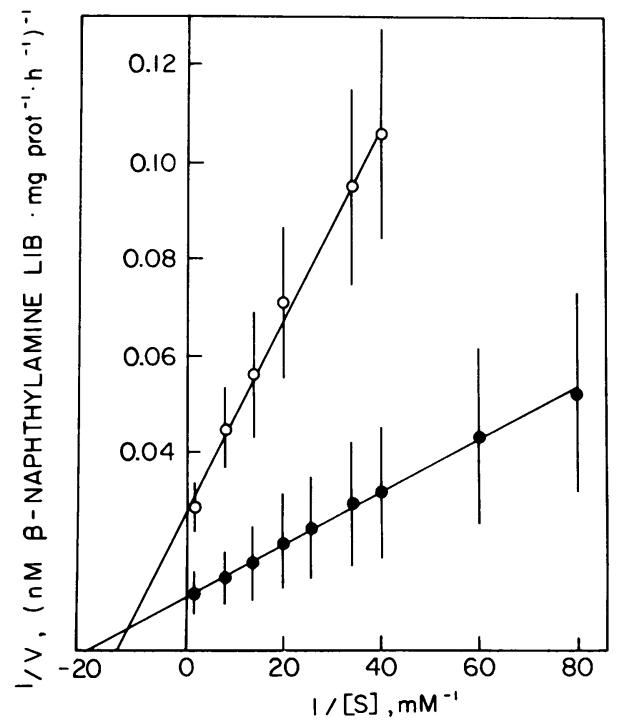

Figure 6 Lineweaver-Burk (double-reciprocal) plot of DAP-I activity vs. substrate concentration (glycyl-phenylalanine- $\beta$-naphthylamide) in normal $(-0-)$ and DMD $(-\mathrm{O}-$ ) cultured human skin fibroblast sonicates. The data are given as the mean $\pm \mathrm{SEM}, n=6$ (normal) or 8 (dystrophic). See Table IV for statistical analysis of individual $K_{m}, V_{\max }$, slope, and $r$ values.
TABLE IV

Kinetic Parameters of DAP-I Activity of Normal and DMD Cultured Human Fibroblasts*

\begin{tabular}{lcccc}
\hline Group & $\mathrm{V}_{\max } \downarrow \S$ & Apparent $K_{\mathrm{m}} \S$ & Slope $\cdot 10^{4} \S$ & $\mathrm{r} \S$ \\
\hline \multicolumn{5}{c}{$m M$} \\
Normal & $224 \pm 75$ & $0.059 \pm 0.005$ & $5.36 \pm 2.10$ & $0.997 \pm 0.001$ \\
DMD & $49 \pm 12^{\prime \prime}$ & $0.065 \pm 0.008$ & $60.9 \pm 44.7^{\prime \prime}$ & $0.993 \pm 0.003$
\end{tabular}

* Mean \pm SEM, $n=6$ (normal) or 8 (DMD).

$\ddagger$ Nanomoles $\beta$-naphthylamine liberated per milligram protein per hour of whole cell sonicates.

$\S$ Determined from linear regression analysis of double reciprocal plots of reaction velocity vs. substrate concentration (1/V vs. 1/S) for each cell line.

"Statistically significant difference from normals, $P<0.03$, two-tailed $t$ test.

population variation and not to deviations from linearity of the points on the individual doublereciprocal plots. Indeed, Table IV shows that the correlation coefficients between $1 / \mathrm{S}$ vs. $1 / \mathrm{V}$ for each cell line approach unity. Table IV also shows that the slight difference in the apparent $K_{\mathrm{m}}$ values between the groups that can be discerned in Fig. 6 is well within the limits of experimental error. Thus, although the activity of DAP-I is clearly lower in the DMD cells as evidenced by decreased $V_{\max }$, the apparent affinity of the enzyme molecule for its substrate is the same for normal and DMD fibroblasts.

Fig. 7 shows the temperature dependence and the activation energy for DAP-I activity calculated from Arrhenius plots (31) of $1 / \mathrm{T}$ vs. the $\log _{10}$ of the reaction rate in the normal and DMD cells. The enzyme from both groups is seen to be stable up to about $60^{\circ} \mathrm{C}$ $\left({ }^{\circ} \mathrm{K}^{-1}=30 \cdot 10^{-4}\right)$, but above this temperature it is rapidly inactivated. This agrees with reports on the heat inactivation properties of DAP-I from other sources (29). It can be seen from Fig. 7 that the temperature dependence and the calculated activation energy for DAP-I activity were the same in the normal and DMD cells.

To investigate the possibility that there is a factor in normal cells but not DMD cells that may stimulate DAP-I activity, different mixtures of normal and DMD cell sonicates were prepared. The presence of a stimulator in excess of optimal concentrations in the normal cells but in suboptimal concentrations in DMD cells would be expected to result in a synergistic effect in the mixed-cell sonicates. Table $\mathrm{V}$ shows that mixtures of cell preparations from the two groups display a strict additivity in DAP-I activity. These data indicate that the normal cells do not contain an excess of a stimulator of DAP-I activity. However, they do not rule out either the presence of a suboptimal concentration of stimulator or the presence in DMD cells of a noncompetitive inhibitor. 


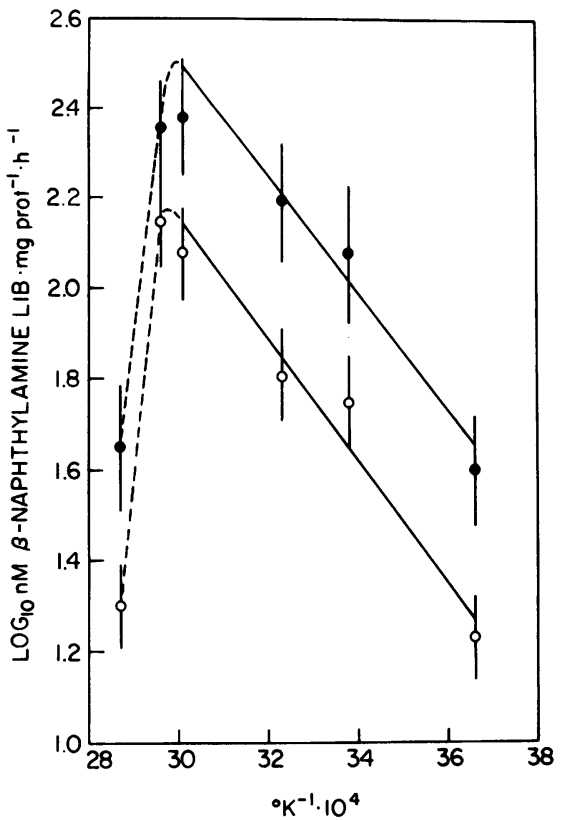

FIGURE 7 The effect of temperature on the rate of hydrolysis of glycyl-L-phenylanine- $\beta$-naphthylamide catalyzed by DAPI of normal ( - - ) and DMD ( $-\mathrm{O}-$ ) cultured human skin fibroblast sonicates assayed for $30 \mathrm{~min}$. The data are plotted as the $\log _{10}$ of the reaction rate vs. the reciprocal of the absolute temperature. The apparent activation energies as calculated from the Arrhenius equation (29) for each individual cell line were (mean $\pm \mathrm{SD}) 5.8 \pm 0.4$ and $5.8 \pm 0.6$ $\mathrm{kcal} / \mathrm{mol}$ for the normal $(n=5)$ and dystrophic $(n=7)$ groups, respectively.

Because of the probable function of DAP-I as an intracellular protease, its broad substrate specificity, and the possibility that it might be representative of a more general alteration in the protease activity of DMD cells, the total autoproteolytic activity in normal and DMD cells was examined. The effect of $\mathrm{pH}$ on the rate of formation of TCA-soluble material from ${ }^{14} \mathrm{C}$ labeled fibroblast protein and values for the specific autoproteolytic activities of the individual cell lines at $\mathrm{pH} 4.0$ are shown in Fig. 8. The sharp optimum at pH 4.0 (Fig. 8A) is different from the $\mathrm{pH}$ profile of DAP-I (Fig. 5) suggesting that other proteases are responsible for the major portion of the proteolytic activity in these cells. The lack of a significant difference between the autoproteolytic activities of DMD and normal groups (Fig. 8B) indicates that the decreased DAP-I activity in DMD cells is a specific effect rather than part of an overall change in proteolytic activity.

\section{DISCUSSION}

The decrease in DAP-I activity in DMD cultured fibroblasts observed in these studies indicates that these cells are metabolically altered in the DMD
TABLE $\mathrm{V}$

DAP-I Activity of Mixtures of Normal and DMD Cultured Skin Fibroblasts

\begin{tabular}{lrcc}
\hline & \multicolumn{3}{c}{ Mean DAP-I activity* } \\
\cline { 2 - 4 } \multicolumn{1}{c}{ Composition of mixture } & Observed & Predicted & $\begin{array}{c}\text { Percentage } \\
\text { of predicted } \\
\text { value }\end{array}$ \\
\hline \multicolumn{1}{c}{ \% by volume } & & & \\
100 Normal & 216 & - & - \\
70 Normal plus 30 DMD & 163 & 165 & 99 \\
50 Normal plus 50 DMD & 135 & 131 & 102 \\
30 Normal plus 70 DMD & 98 & 96 & 102 \\
100 DMD & 45 & - & - \\
\hline
\end{tabular}

* Nanomoles $\beta$-naphthylamine liberated per milligram protein per hour at $37^{\circ} \mathrm{C}$. Values given are the means of three replicate trials performed using pools of normal and DMD whole cell sonicates. All assays were performed at the same final protein concentration.

$\$$ Chi-square equal to $0.65,0.87$, and 0.22 for the three trials (d.f. $=2$ ), $0.6<P<0.9$, indicating that the observed values do not deviate from the additive prediction.

population, although this change appears to be noncritical with respect to the growth and viability of the cells. The question of whether the decreased DAP-I activity represents a defective gene product in the form of an altered DAP-I molecule was addressed by comparing several physical and chemical properties of DAP-I activity in normal and DMD fibroblasts. The results of these studies have shown that DAP-I activity existing in normal and DMD fibroblasts behaves

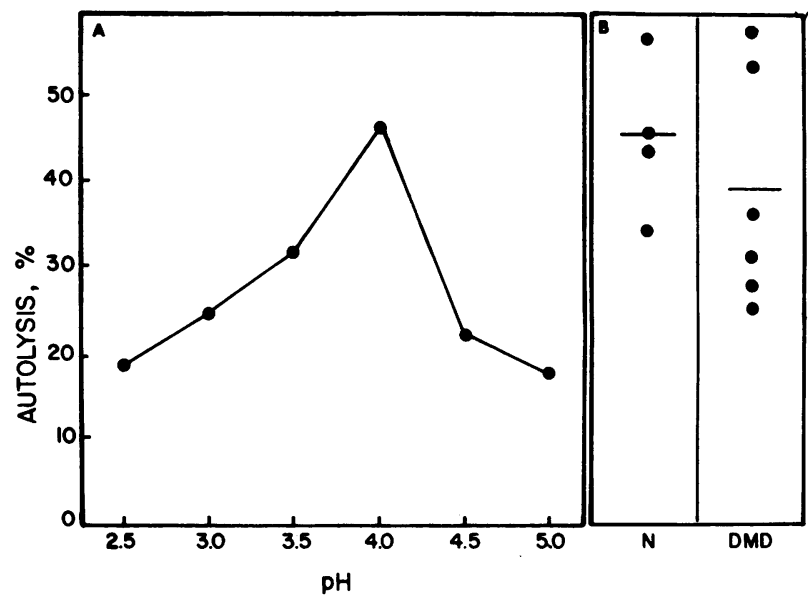

FIGURE 8 Autoproteolytic activity of disrupted human fibroblasts. Cell proteins were labeled with ${ }^{14} \mathrm{C}$ and the cells disrupted as described in Methods, and the $\mathrm{pH}$ optimum (panel A) was determined on a sample of pooled cell lines. In panel $B$ the autoproteolytic activity expressed as the present of total TCA precipitable counts that were solubilized after $3.5 \mathrm{~h}$ at $37^{\circ} \mathrm{C}$ was determined for each individual cell line at $\mathrm{pH}=4.0$. There was no statistically significant difference between the normal and DMD cells. 
identically with respect to activation by chloride ion, activation by the sulfhydryl reducing agent DTT, changes in hydrogen ion concentration $(\mathrm{pH})$, changes in substrate concentration (i.e., apparent $K_{\mathrm{m}}$ values), and changes in temperature (i.e., apparent activation energies). These findings offer substantial support for the conclusion that the DAP-I molecule is structurally equivalent between normal and DMD fibroblasts and that the decrease in tissue-specific DAP-I activity is likely to result from the fact that fewer enzyme molecules are present in the DMD cells. It is our belief that the decrease in DAP-I is a secondary phenomenon and does not represent the primary lesion in the disease. Furthermore, associated with the loss of enzyme activity, there is also a decrease in the structure-linked latency of DAP-I in DMD cells suggestive of an alteration in lysosomal membrane structure (our unpublished observations).

Alternatively, the DMD cells could contain a DAP-I inhibitor or the normal cells could contain a DAP-I stimulator. That there is no competitive inhibitor of DAP-I present in the DMD cells is indicated by the identical values for $K_{\mathrm{m}}$ in normal and DMD cells (Fig. 5 and Table IV). The presence of a DAP-I stimulator in normal cells can be partially ruled out from the data of Table $V$ showing additivity of mixed DMD and normal cell activities but the presence of suboptimal stimulator levels remains a possibility. On the other hand, it is almost impossible to eliminate the existence of a noncompetitive inhibitor of DAP-I using an unpurified enzyme preparation as was the case in these studies.

It is important to note that all of these experiments on the properties of the fibroblast enzyme have used a nonpurified preparation and could therefore be misleading if the specificity of the glycyl-phenylalanine$\beta$-naphthylamide assay system were not absolute for DAP-I. However, several facts argue persuasively against this possibility. First, DAP-I has an unusual combination of properties and cofactor requirements, including activity at acid $\mathrm{pH}$, a sulfhydryl requirement, and a highly unusual requirement for chloride ion that is virtually absolute (29). All of these characteristics were clearly demonstrated in our fibroblast enzyme assay. Second, the fluorogenic substrate used in these studies is generally accepted as being quite specific for DAP-I $(29,32)$. Third, DAP-I activity displayed a sedimentation pattern on sucrose density gradients identical to other characteristic lysosomal enzymes, confirming the lysosomal localization of the enzyme. Fourth, we have observed that DAP-I activity displays a latency phenomenon after treatment with detergents that is quantitatively equivalent to the latency characteristics of other lysosomal enzymes (data not shown), further demonstrating the lysosomal character of the fibroblast enzyme. Finally, we have also tested another DAP-I-specific substrate, glycyl-arginine- $\beta$ - naphthylamide, and found the same decrease in DMD specific activity with the same statistical validity (data not shown).

Previous investigations on muscle tissue from DMD patients (11-17) have reported increases in lysosomal protease activity, whereas the results reported here show that total acid autoproteolysis as well as a number of specific lysosomal enzymes are unchanged in DMD fibroblasts. Indeed, one report (13) has shown, contrary to our results on DMD fibroblasts, that DAP-I activity is increased in DMD muscle. The reason for this apparent discrepancy is not clear but it would support the belief that lysosomal "activation" in DMD muscle biopsies is a nonspecific tissue response to injury as opposed to the primary mechanism of cellular degeneration (1). It is also well known that muscle tissue in DMD patients is undergoing extensive invasion by fibroblasts, macrophages, and fat cells (it is this invasion that gives rise to the pseudohypertrophy characteristic of this disease). The specific activity of DAP-I in human muscle is $36 \mathrm{nM} / \mathrm{mg}$ protein per $h$ (13), whereas in cultured fibroblasts it averages 1,988 and $487 \mathrm{nM} / \mathrm{mg}$ protein per $\mathrm{h}$ for normal and DMD cells, respectively (our data). Consequently, invasion of DMD muscle by other cells in which only $2-8 \%$ of the total cellular protein were replaced by fibroblasts would be sufficient to cause an apparent $100 \%$ increase in DAP-I activity. This could therefore account for the observed activation of DAP-I in DMD muscle (13).

Although the magnitude and statistical significance of the decreased DAP-I activity in DMD fibroblasts reported here are readily apparent, it must be remembered that the range of DAP-I values in the two sample populations of cells does overlap. Thus, decreased fibroblast DAP-I activity per se is probably not a pathognomonic marker for the DMD population. Furthermore, in the absence of any data on other neuromuscular disease control cell lines, it is difficult to assess the specificity of this abnormality. On the other hand, these results do warrant further study of this fibroblast enzyme on larger sample populations so that the precision of the predictive value of this biological indicator can be determined more accurately.

The relationship of the decrease in DAP-I activity in DMD fibroblasts to the overall physiology and metabolism of these cells is presently unknown. The biochemical specificity of the enzyme for cleavage of certain amino terminal dipeptidyl groupings is well characterized $(29,32)$ but identification of specific physiological protein and/or peptide substrates for the enzyme, the mode of DAP-I regulation and turnover, and the overall role of DAP-I in cellular metabolism are not clear. Further studies of the regulation, turnover, and function of DAP-I in normal and DMD human fibroblasts may yield valuable clues in defining the precise metabolic defect in DMD. Whatever the 
physiological significance of decreased fibroblast DAP-I activity may be, these results support the suggestion that these nonmuscle cells are expressing at least some of the phenotypic consequences of the genetic defect in DMD.

\section{ACKNOWLEDGMENTS}

We thank Dr. F. J. Samaha and Dr. S. Iannaccone for providing skin biopsies from the Neurological Clinic of the University of Cincinnati Medical Center, and Mrs. Marcia McLachlan for her excellent secretarial assistance in the preparation of the manuscript.

This work was supported by a grant from the Muscular Dystrophy Association of America.

\section{REFERENCES}

1. Appel, S. H., and A. D. Roses. 1978. The muscular dystrophies. In The Metabolic Basis of Inherited Disease. J. B. Stanbury, J. B. Wyngaarden, and D. S. Frederickson, editors. McGraw-Hill Book Company, New York. 4th edition. 1260-1281.

2. Kunzé, G., E. Reichmann, E. Egger, D. Olthoff, and K. Döhler. 1975. Fatty acid pattern of lipids in normal and dystrophic human muscle. Eur. J. Clin. Invest. 5: 471-475.

3. West, D. P., D. A. Ellis, and J. M. Strickland. 1977. Incorporation of $\left[\mathrm{U}_{-14}{ }^{14} \mathrm{C}\right]$ glucose into neutral lipids and $s n$-glycerol-3-phosphate in muscle from Duchenne Muscular Dystrophy and control patients. J. Neurol. Sci. 33: $131-142$.

4. Susheela, A. K., R. D. Kaul, K. Sachdeva, and N. Singh. 1975. Adenyl cyclase activity in Duchenne dystrophic muscle. J. Neurol. Sci. 24: 361-363.

5. Mawatari, S., A. Miranda, and L. Rowland. 1976. Adenyl cyclase abnormality in Duchenne Muscular Dystrophy: muscle cells in culture. Neurology. 26: 1021-1026.

6. Takahashi, K., H. Takao, and T. Takai. 1978. Adenylate cyclase in Duchenne and Fukuyama type muscular dystrophy. Kobe J. Med. Sci. 24: 193-198.

7. Samaha, F. J. 1977. Sarcotubular system in the muscular dystrophies. In Pathogenesis of Human Muscular Dystrophies. L. P. Rowland, editor. Excerpta Medica, Amsterdam-Oxford. 633-641.

8. Ionasescu, V., H. Zellweger, R. Ionasescu, C. Lara-Braud, and P. A. Cancilla. 1976. Protein synthesis in muscle cultures from patients with Duchenne Muscular Dystrophy. Acta Neurol. Scand. 54: 241-247.

9. Mokri, B., and A. G. Engel. 1975. Duchenne dystrophy: electron microscopic findings pointing to a basic or early abnormality in the plasma membrane of the muscle fiber. Neurology. 25: 1111-1120.

10. Schotland, D. L., E. Bonilla, and M. Van Meter. 1977. Duchenne dystrophy: alteration in muscle plasma membrane structure. Science (Wash. D. C.). 196: 1005-1007.

11. Kar, N. C., and C. M. Pearson. 1972. Acid, neutral and alkaline cathepsins in normal and diseased human muscle. Enzyme (Basel). 13: 188-196.

12. Kar, N. C., and C. M. Pearson. 1976. A calcium-activated neutral protease in normal and dystrophic human muscle. Clin. Chim. Acta. 73: 293-297.

13. Kar, N. C., and C. M. Pearson. 1978. Dipeptidyl peptidases in human muscle disease. Clin. Chim. Acta. 82: 185-192.

14. Kar, N. C., and C. M. Pearson. 1979. Activity of some proteolytic enzymes in normal and dystrophic human muscle. Clin. Biochem. 12: 37-39.

15. Katunuma, N., N. Yasogawa, K. Kito, Y. Sanada, H. Kawai, and K. Miyoshi. 1978. Abnormal expression of a serine protease in human dystrophic muscle. J. Biochem. 83: 625-628.

16. Mayer, M., and E. Shafrir. 1977. Skeletal muscle protease and glucocorticoid hormone receptors in muscle wasting conditions and muscular dystrophy. Isr. J. Med. Sci. 13: $139-146$.

17. McKeran, O., D. Halliday, and P. Purkiss. 1977. Increased myofibrillar protein catabolism in Duchenne muscular dystrophy measured by 3-methylhistidine excretion in the urine.J. Neurol. Neurosurg. Psychiatry. 40: 979-981.

18. Pena, S. D. J., V. D. Tucker, J. L. Hamerton, and K. Wrogemann. 1978. Biochemical investigations in cultured skin fibroblasts from patients with Duchenne muscular dystrophy. Clin. Genet. 14: 50-54.

19. Ionasescu, V., C. Lara-Braud, H. Zellweger, R. Ionasescu, and L. Burmeister. 1977. Fibroblast cultures in Duchenne muscular dystrophy. Alterations in synthesis and secretion of collagen and noncollagen proteins. Acta Neurol. Scand. 55: 407-417.

20. Wyatt, P. R., and D. M. Cox. 1977. Duchenne's muscular dystrophy: studies in cultured fibroblasts. Lancet. I: 172-174.

21. Cullen, M. J., and R. Parsons. 1977. Inclusion bodies in muscular dystrophy. Lancet. II: 929.

22. Stevens, H. R., M. J. Dunn, and V. Dubowitz. 1979. Collagen and non-collagen protein synthesis in skin fibroblasts from patients with Duchenne Muscular Dystrophy. Fourth International Biochemistry Congress. Toronto, Canada. 653 (Abstr.)

23. Boulé, M., M. Vanasse, L. Brakier-Gingras. 1979. Variations in the rate of protein synthesis in Duchenne Muscular Dystrophy. Fourth International Biochemistry Congress. Toronto, Canada. 653 (Abstr.)

24. Pickard, N. A., H. Gruemer, H. L. Verrill, E. R. Isaacs, M. Robinow, W. E. Nance, E. C. Myers, and B. Goldsmith. 1978. Systemic membrane defect in the proximal muscular dystrophies. N. Engl. J. Med. 299: 841-846.

25. Peters, T. J., M. Müller, and C. deDuvé. 1972. Lysosomes of the arterial wall. I. Isolation and subcellular fractionation of cells from normal aorta. J. Exp. Med. 136: 11171139.

26. Rome, L. H., A. J. Garvin, M. M. Allietta, and E. F. Neufeld. 1979. Two species of lysosomal organelle in cultured human fibroblasts. Cell. 17: 143-153.

27. Lowry, O. H., N. J. Rosebrough, A. L. Farr, and R. J. Randall. 1951. Protein measurement with the Folin phenol reagent. J. Biol. Chem. 193: 265-275.

28. Remington, R. D., and A. M. Schork. 1970. Statistics With Applications to the Biological Health Sciences. Prentice-Hall, Inc., Englewood Cliffs, N. J. 192-224.

29. McDonald, J. K., and C. Schwabe. 1977. Intracellular exopeptidases. In Proteinases in Mammalian Cells and Tissues. A. J. Barrett, editor. North Holland Publishing Company, Amsterdam. 310-391.

30. Metrione, R. M., A. G. Neves, and J. S. Fruton. 1966. Purification and properties of dipeptidyl transferase (Cathepsin C). Biochemistry. 5: 1597-1604.

31. White, A., P. Handler, and E. L. Smith. 1973. Principles of Biochemistry. McGraw-Hill Book Company, Inc., New York. 5th edition. 232-235.

32. McDonald, J. K., B. B. Zeitman, T. J. Reilly, and S. Ellis. 1969. New observations on the substrate specificity of cathepsin C (dipeptidyl aminopeptidase I). J. Biol. Chem. 244: 2693-2709. 